\title{
Fallopian tube herniation from trocar-site after laparoscopic appendectomy
}

\author{
(D) Anıl Ergin, M.D., (1) Yalın İşcan, M.D., (1) Birol Ağca, M.D., \\ Bora Karip, M.D., Kemal Memişoğlu, M.D.
}

Department of General Surgery, University of Health Sciences, İstanbul Fatih Sultan Mehmet Training and Research Hospital, İstanbul-Turkey

\begin{abstract}
Trocar site hernias are a type of incisional hernias and may occur within a variable time shift after surgery.A mean incidence of $1.85 \%$ was reported, and the first trocar site hernia was narrated by Maio et al. in 1991 describing small bowel obstruction due to trocar site herniation after laparoscopic cholecystectomy. The 10 - $\mathrm{mm}$-trocar port is more frequently problematic, and a trocar site hernia in $5 \mathrm{~mm}$ port is very rare. This report unveils a $5 \mathrm{~mm}$ trocar site herniation of right fallopian tube following laparoscopic appendectomy. In this case study, a 19-year-old female patient applied to the emergency department because of a discharge in the right lower quadrant was reported. She explained that she had undergone laparoscopic appendectomy two days before and discharged the next day uneventfully. The surgical report described a suction drain in the right lower quadrant where the patient was suffering from the discharge. The physical examination revealed no tenderness, but an abdominal CT disclosed an edematous tubular structure herniating from the $5 \mathrm{~mm}$ trocar site where the drain was put. She was re-operated laparoscopically due to early trocar site hernia, and the right fallopian tube was observed herniating through the defect.After the reduction into the abdomen, the fallopian tube was observed fine, and the defect was closed using 2/0 polypropylene suture. Trocar site hernias are rare but may cause serious complications after laparoscopic surgery. They may occur early after the surgery, but the time shift is variable. Although mechanical bowel obstructions are more frequent endpoint, it should be remembered that any organ within the abdominal cavity may herniate.
\end{abstract}

Keywords: Fallopian tube; laparoscopic appendectomy; trocar site hernia.

\section{INTRODUCTION}

After abdominal surgery, negative features, such as pain, wound infection and development of the incision hernia, are less common in laparoscopy compared to open surgery. [1] The laparoscopic approach offers advantages, such as low blood loss, short hospital stay and early return to work. ${ }^{[2]} \mathrm{Be}-$ sides, laparoscopic surgery may cause complications, such as vascular injuries, bowel injuries, nerve damage and incisional hernia. ${ }^{[3]}$ The definition of trocar site hernias is used for incisional hernias formed after laparoscopic surgery, or trocar site hernias are rare complications. The incidence is between $1 \%$ and $6 \%$. When the literature is reviewed, trocar site hernia is most commonly seen in $10 \mathrm{~mm}$ trocar sites. ${ }^{[4]}$ Many surgeons do not repair the trocar sites of $5 \mathrm{~mm}$ because a hernia will not be developed from this size of the defect. ${ }^{[5]}$ In this case report, a case in which the detection of fallopian tube herniation in a $5 \mathrm{~mm}$ trocar site in a patient who had undergone laparoscopic appendectomy was presented.

\section{CASE REPORT}

In the physical examination of a 19-year-old female patient, who was discharged on the first postoperative day after the laparoscopic appendectomy and applied to Emergency Room with a complaint of drainage in the right lower quadrant and appearance of fatty tissue on the postoperative second day, an edematous fatty tubular structure that cannot be reduced

Cite this article as: Ergin A, İşcan Y, Ağca B, Karip B, Memişoğlu K. Fallopian tube herniation from trocar-site after laparoscopic appendectomy. Ulus Travma Acil Cerrahi Derg 2020;26:639-641.

Address for correspondence: Anıl Ergin, M.D.

Sağlık Bilimleri Üniversitesi, İstanbul Fatih Sultan Mehmet Eğitim ve Araştırma Hastanesi, Genel Cerrahi Kliniği, İstanbul, Turkey

Tel: +90 216 - 5783000 E-mail: dranilergin@gmail.com

Ulus Travma Acil Cerrahi Derg 2020;26(4):639-64I DOI: 10.14744/tjtes.2019.7246I Submitted: 2I.II.2018 Accepted: 30.07.2019 Online: I5.06.2020

Copyright 2020 Turkish Association of Trauma and Emergency Surgery 
at the port entrance site of the right lower quadrant and serosal drainage from this structure was observed (Fig. I). Acute abdomen findings were not observed in the abdominal examination. In laboratory values, hemoglobulin: $12.3 \mathrm{gr} /$ dl white blood cell: $14.2 \times 10^{3} / \mathrm{UL}$, C-reactive protein: $4 \mathrm{mg} /$ dl. In the retrospective examination of the patient, it was learned that the patient underwent laparoscopic appendectomy for perforated appendicitis was inserted an aspiration drain to her Douglas space from the 5-mm trocar site in the right lower quadrant, and it was removed in the second day after the operation. In the computed tomography taken in the emergency room, a tubular structure with an edematous appearance, which is herniated from the $5 \mathrm{~mm}$ trocar site in the right lower quadrant, was identified (Fig. 2). With the consideration of an early trocar site herniation, the patient underwent a laparoscopic exploration intended surgery. During exploration, the right fallopian tube was seen, which was herniated from a $5 \mathrm{~mm}$ trocar site (Fig. 3). After the fallopian tube was rejected into the abdomen, the defect area was repaired with the endoclose, with the help of a transfacial 2.0

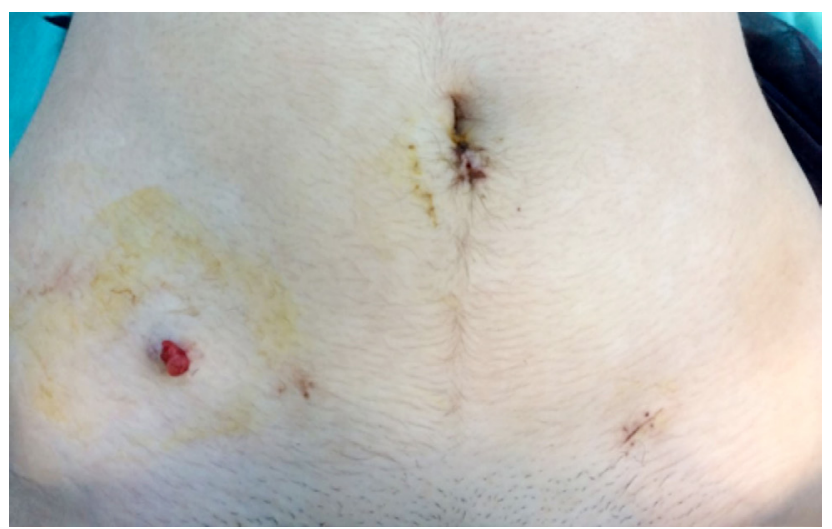

Figure 1. Fatty tissue in the trocar site.

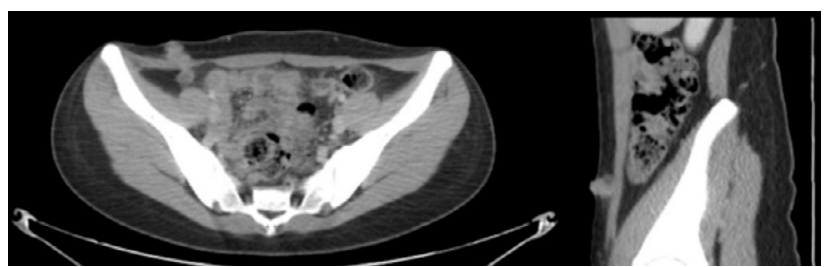

Figure 2. Tubular structure with an edematous appearance in the computed tomography.

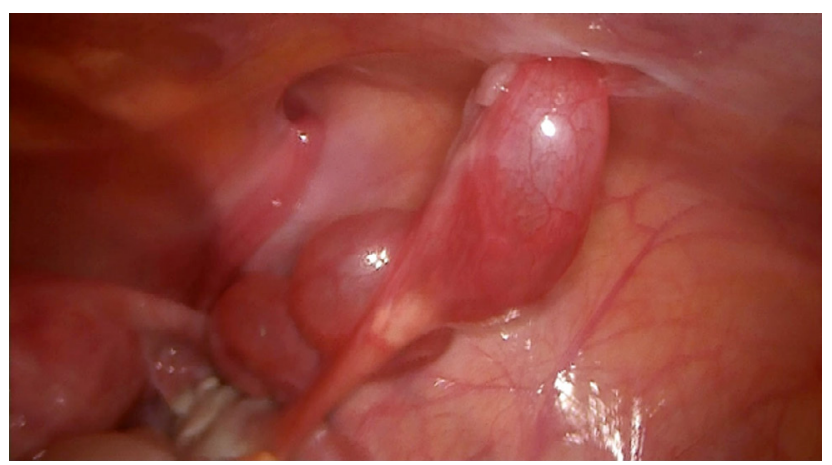

Figure 3. Herniated right fallopian tube in $5 \mathrm{~mm}$ trocar site. polypropylene suture. The patient, who had no postoperative complications, was discharged on the first postoperative day. Patient's consent was obtained for this study.

\section{DISCUSSION}

Compared to open surgery, laparoscopic surgery has become a more preferred method in a wide area. The advantages, such as pain, rapid recovery and low incisional hernia rate, are ensuring to be more preferred. ${ }^{[1]}$ However, it has been known since 1967 that laparoscopic surgery may also cause trocar site hernias. ${ }^{[6]}$ Several risk factors have been identified in the literature regarding the trocar site hernia. Trocar size and location, finding the pre-existing facial defects, expanding the trocar insertion site to remove the specimen, high blood glucose levels, obesity, increased intra-abdominal pressure due to chronic obstructive pulmonary diseases are some of these risk factors. However, the most effective among these risk factors was determined as trocar size. The hernia rates developed from $12 \mathrm{~mm}$ and $10 \mathrm{~mm}$ trocar sites are significantly higher than the ones developed from $5 \mathrm{~mm}$ and $3 \mathrm{~mm}$ trocar sites. ${ }^{[7]}$ Thus, Sanz-López et al. ${ }^{[8]}$ have recommended the repair of trocar insertion site defects larger than $5 \mathrm{~mm}$. It is recommended that $5-\mathrm{mm}$ trocar sites should only be closed in cases where the port site is manipulated for various reasons. ${ }^{[9]}$ Another important issue in the prevention of postoperative trocar site hernia is trocar insertion sites. Trocars inserted from the midline (especially the trocar inserted from the umbilical area) are the most common sites of herniation. [7] The reason for this is thought to be the presence of fascia as a single leaf at Linea Alba align, and the presence of a natural defect area, such as umbilicus. In the literature, review of Ben-Shian Huang et al., ${ }^{[10]}$ only one case in which the fallopian tube was herniated from 5-mm trocar was found. A 9-year-old boy who underwent laparoscopic cystectomy was admitted to the emergency room with complaints of pain on the left lower quadrant and a palpable mass in the trocar site in the lower left quadrant on the seventh postoperative day. In this case, laparotomy was preferred for the treatment, and fallopian tube excision was performed. ${ }^{[1 I]}$

In our case, although there was no risk factor for the development of trocar site herniation, a 5-mm trocar site hernia was developed. Therefore, it should be kept in mind that there may be herniation from a $5 \mathrm{~mm}$ trocar sites without any risk factors, and herniation of the abdominal organs from these defect sites is possible. This case report is the first $5 \mathrm{~mm}$ trocar site fallopian tube herniation case treated laparoscopically.

\section{Conclusion}

Regardless of the size of the trocar, after laparoscopic surgery, trocar site hernias may cause serious early and late complications. Although mechanical intestinal obstruction is typically came to mind in trocar site hernias, it should be kept in mind that any intra-abdominal organ may be herniated from this site. 
Informed Consent: Written informed consent was obtained from the patient for the publication of the case report and the accompanying images.

Peer-review: Internally peer-reviewed.

Authorship Contributions: Concept: A.E.; Design: A.E.; Supervision: Y.I.; Fundings: Y.I.; Materials: B.A.; Data: B.K.; Analysis: A.E.; Literature search: A.E.; Writing: A.E.; Critical revision: K.M.

\section{Conflict of Interest: None declared.}

Financial Disclosure: The authors declared that this study has received no financial support.

\section{REFERENCES}

1. Tan S, Wu G, Zhuang Q, Xi Q, Meng Q, Jiang Y, et al. Laparoscopic versus open repair for perforated peptic ulcer: A meta analysis of randomized controlled trials. Int J Surg 2016;33:124-32. [CrossRef]

2. Trejo-Ávila ME, Valenzuela-Salazar C, Betancourt-Ferreyra J, Fernández-Enríquez E, Romero-Loera S, Moreno-Portillo M. Laparoscopic Versus Open Surgery for Abdominal Trauma: A Case-Matched Study.
J Laparoendosc Adv Surg Tech A 2017;27:383-7. [CrossRef]

3. Nezhat C, Nezhat F, Seidman DS, Nezhat C. Incisional hernias after operative laparoscopy. J Laparoendosc Adv Surg Tech A 1997;7:111-5.

4. Bunting DM. Port-site hernia following laparoscopic cholecystectomy. JSLS 2010;14:490-7. [CrossRef]

5. Agha RA, Fowler AJ, Saeta A, Barai I, Rajmohan S, Orgill DP; SCARE Group. The SCARE Statement: Consensus-based surgical case report guidelines. Int J Surg 2016;34:180-6. [CrossRef]

6. Fear RE. Laparoscopy: a valuable aid in gynecologic diagnosis. Obstet Gynecol 1968;31:297-309. [CrossRef]

7. Tonouchi H, Ohmori Y, Kobayashi M, Kusunoki M. Trocar site hernia. Arch Surg 2004;139:1248-56. [CrossRef]

8. Sanz-López R, Martínez-Ramos C, Núñez-Peña JR, Ruiz de Gopegui $\mathrm{M}$, Pastor-Sirera L, et al. Incisional hernias after laparoscopic vs open cholecystectomy. Surg Endosc 1999;13:922-4. [CrossRef]

9. Munro MG. Laparoscopic access: complications, technologies, and techniques. Curr Opin Obstet Gynecol 2002;14:365-74. [CrossRef]

10. Huang BS, Seow KM, Tsu KH, Su WH, Lu CH, Wang PH. Small trocar site hernia after laparoscopy. Gynecology and Minimally Invasive Therapy 2013;2:79-84. [CrossRef]

11. Wang PH, Yen MS, Yuan CC, Liang SC, Lin JY. Incarcerated hernia in a 5-mm cannula wound. J Am Assoc Gynecol Laparosc 2001;8:449-52.

\section{OLGU SUNUMU - ÖZET}

\section{Laparoskopik apendektomi sonrası trokar yerinden fallop tüpü herniasyonu}

\section{Dr. Anıl Ergin, Dr. Yalın Iş̧can, Dr. Birol Ağca, Dr. Bora Karip, Dr. Kemal Memişoğlu}

Sağlık Bilimleri Üniversitesi, İstanbul Fatih Sultan Mehmet Eğitim ve Araştırma Hastanesi, Genel Cerrahi Kliniği, İstanbul

Trokar yeri hernisi bir insizyonel herni tipi olup ameliyattan sonra farklı zaman dilimlerinde karşımıza çıkabilmektedir. Ortalama insidansı \%।.85 olup ilk kez Maio ve ark. tarafından 1991 ylında laparoskopik kolesistektomi sonrası ince bağırsak obstrüksiyonu ile birlikte trokar yeri herniasyonu gelişimini bildirilmiştir. Genellikle 10 mm'lik trokar girişlerinde görülebilen bu durum 5 mm'lik trokar girişlerinde ise nadiren görülmektedir. Bu yazıda, laparoskopik apendektomi sonrasında 5 mm'lik trokar yerinde gelişen, sağ fallop tüpü herniasyonu olgusu sunuldu. On dokuz yaşında kadın hasta, acil polikliniğimize sağ alt kadrandaki insizyon yerinde akıntı ve sağ alt kadran ağrısı şikayetiyle başvurdu. Öyküsünde iki gün önce kliniğimizde akut apandisit tanıı ile laparoskopik apendektomi uygulanmıştı. Ameliyat lojuna bir adet aspiratif dren konarak ameliyat sonlandırıldı. Ameliyat sonrası birinci gün dreni alınıp şifa ile taburcu edildi. Acil poliklinik muayenesinde sağ alt kadrandaki insizyonundan serozal akıntı ve milimetrik yağı doku evantrasyonu izlenildi. Olguda akut karın bulguları saptanmadı. Akut faz reaktanları normal, yapılan bilgisayarlı tomografide plevik bölgeden sağ alt kadran kesi bölgesine uzanan hidropik tubuler bir yapı izlendi. Bunun üzerine erken dönem gelişen trokar herni ön tanısı ile ameliyata alındı. Laparoskopik eksplorasyonda sağ fallop tüpünün hidropik ve ödemli olduğu ve 5 mm'lik trokar yerine herniye olduğu görüldü. Fallop tüpü laparoskopik olarak redükte edilip batın içerisine alındı. Trokar yerindeki açıkık ise $2 / 0$ prolen ile dikildi. Olgumuz ameliyat sonrası birinci gün şifa ile taburcu edildi. Trokar yeri hernileri laparoskopik cerrahi sonrasında nadir görülmekle birlikte ciddi komplikasyonlardan biridir. Laparoskopik ameliyatlardan sonra erken veya geç dönemlerde gelişebilecek olan bu durumda daha çok mekanik bağırsak tıkanmaları gözüksede diğer intraperitoneal organlarında herniye olabileceği akılda tutulmalıdır.

Anahtar sözcükler: Fallop tüpü, laparoskopik apendektomi; trokar yeri hernisi.

Ulus Travma Acil Cerrahi Derg 2020;26(4):639-64| doi: |0.14744/tjtes.2019.7246 | 